\title{
Impacts of Cropping Systems and Long-Term Tillage on Soil Microbial Population Levels and Community Composition in Dryland Agricultural Setting
}

\author{
Justin P. Ng, ${ }^{1,2}$ Emily B. Hollister, ${ }^{1}$ Ma. del Carmen A. González-Chávez, ${ }^{2}$ \\ Frank M. Hons, ${ }^{1}$ David A. Zuberer, ${ }^{1}$ Jacqueline A. Aitkenhead-Peterson, ${ }^{1}$ \\ Richard Loeppert, ${ }^{1}$ and Terry J. Gentry ${ }^{1}$ \\ ${ }^{1}$ Soil and Crop Sciences Department, Texas A\&M University, College Station, TX 77843-2474, USA \\ ${ }^{2}$ Programa de Edafología, Colegio de Postgraduados en Ciencias Agrícolas, Campus Montecillo, Carr. México-Texcoco, \\ 56230 Montecillo, MEX, Mexico \\ Correspondence should be addressed to Justin P. Ng, justin.ng@tamu.edu
}

Received 28 September 2011; Accepted 18 October 2011

Academic Editor: R. Abed

Copyright () 2012 Justin P. Ng et al. This is an open access article distributed under the Creative Commons Attribution License, which permits unrestricted use, distribution, and reproduction in any medium, provided the original work is properly cited.

Few studies have used molecular methods to correlate the abundance of specific microbial taxonomic groups with changes in soil properties impacted by long-term agriculture. Community qPCR with $16 \mathrm{~S}$ rRNA gene sequencing to examine the effects of long-term crop-management practices (no-till vs. conventional tillage, and continuous wheat (Triticum aestivum L.) vs. sorghumwheat-soybean rotation (Sorghum bicolor L. Moench-Triticum aestivum L.-Glycine max L. Merr) on bacterial and fungal relative abundances and identify the dominant members of the soil microbial community. The qPCR assays revealed that crop rotation decreased bacterial copy numbers, but no-till practices did not significantly alter bacteria or fungi relative to conventional tillage. Cyanobacteria were more abundant while Actinobacteria were less numerous under continuous wheat. Acidobacteria and Planctomycetes were positively correlated with soil microbial biomass $\mathrm{C}$ and $\mathrm{N}$. This study highlights ways cropping systems affect microbial communities and aids the development of sustainable agriculture.

\section{Introduction}

The effects of modern agriculture on soil microbial communities are very complex; yet understanding them is important for the effective and sustainable management of agricultural ecosystems [1]. Both no-till and crop rotations have been widely adopted in many agricultural settings, and although it is generally accepted that these practices have the potential to increase microbial biomass and activity $[2,3]$, the specific impacts that these practices have on microbial community composition are largely unknown. Frey et al. [4] reported no consistent effects on bacterial abundance or biomass in a 30-year tillage plot. Other studies have indicated that tilled soil may or may not contain greater bacterial diversity than nontilled soil [5-7]. Tillage typically has exhibited more consistent, predictable effects on soil fungal populations, often resulting in the inhibition of active soil hyphae and arbuscular mycorrhizal fungi [8-11]. Long-term studies (2530 years) have found that fungal biomass and hyphal lengths increase with no-tillage compared to conventional tillage [4, 12]. However, reported results have been mixed as to whether no-tillage practices have a greater impact on bacterial or fungal populations $[3,12]$.

Similarly, varying outcomes have been reported with respect to the effects of monoculture production versus crop-rotation on soil microbial communities. Some studies suggest that monocultures select for less diverse microbial communities, with research indicating that monocultures of wheat (Triticum aestivum L.), maize (Zea mays L.), or soybean (Glycine $\max$ L.) may lead to reduced levels of metabolic diversity [13], the dominance of certain genotypes of Rhizobium [14], or the decline of fungal species [15], respectively. In addition, it has been reported that potato (Solanum tuberosum L.) monocultures result in an increased 
abundance of plant pathogens, leading to a decline in both crop yield and quality $[16,17]$. In contrast, other studies have reported that long-term rotations of wheat and maize do not appear to significantly impact total bacterial populations but may alter diversity by specifically decreasing the abundance of fluorescent Pseudomonas spp. [18, 19].

An explanation for these mixed results may lie in the variety of different microbial characterization methods that have been used. Most of this research to date has been conducted using techniques such as plate counts, community level physiological profiles, fatty acid methyl ester analysis (FAME), and phospholipid fatty acid analysis (PLFA). A smaller number of studies have used DNA fingerprinting approaches, such as denaturing gradient gel electrophoresis $[20,21]$, but these methods also tend to have limited ability to resolve phylogenetic differences in community composition. Even fewer studies have used DNA sequencing [7, 22], which typically provides more detailed basis for phylogenetic comparison of soil microbial communities.

For more than 25 years, data have been collected on the effects of tillage and cropping sequences on crop yields and soil chemical, physical, and biological properties from a dryland farming system in south central Texas [2, 2325]. These data indicate that many soil properties, including soil aggregate formation and organic $\mathrm{C}$ and $\mathrm{N}$ storage, have improved significantly in response to the no-tillage and crop-rotation practices. Additionally, recent microbial analyses indicated that microbial related properties, including concentrations of soil carbohydrates and glomalin-related soil proteins (GRSP), increased in the no-tillage plots [26]. Using FAME analysis, González-Chávez et al. [26] also found that the no-tillage soils contained greater proportions of bacteria relative to fungi, as well as different and more diverse microbial communities than those in continuous tillage plots. Although this study revealed that the treatments had altered the soil microbial communities, it provided limited information on the specific microbial populations that were affected. In order to complement and expand upon the microbial characterization of these systems, we used quantitative PCR (qPCR) to enumerate bacterial and fungal populations and 16S rRNA sequencing to compare bacterial community composition in the various tillage and rotation treatments. We hypothesized that a combination of no-tillage and crop-rotation practices would result in an increased abundance of bacteria and fungi [26, 27] and an increased phylogenetic diversity [28] characterized by higher percentage of the phyla Actinobacteria [7]. Our objective was to determine the impacts of management systems on soil microbial communities. It is anticipated that this research will provide useful information in the design of sustainable agricultural management systems.

\section{Materials and Methods}

2.1. Site Description and Sampling. The soil samples used in this study were collected from a dryland farming system trial initiated in 1982 in south-central Texas at the Texas A\&M University Research Farm near College Station, TX $\left(30^{\circ} 32^{\prime} \mathrm{N}\right.$, $\left.94^{\circ} 26^{\prime} \mathrm{W}\right)$. The climate of this region is classified as humid, subtropical with a long-term average annual temperature of $20^{\circ} \mathrm{C}$ (average maximum monthly high: $35.8^{\circ} \mathrm{C}$, average minimum monthly low: $3.5^{\circ} \mathrm{C}$ ) and annual rainfall of $978 \mathrm{~mm}[2,26]$. The soil at this site is a Westwood silty clay loam and has been characterized as a fine silty, mixed, thermic Fluventic Ustochrept by US Soil Taxonomy [2] and a Fluvic Cambisol (Calcaric, Eutric) by the International World Reference Base.

Two tillage regimes and two cropping sequences were sampled for our study: (1) no-till, continuous wheat (NTCW; Triticum aestivum L.); (2) conventional till, continuous wheat (CT-CW); (3) no-till, sorghum (Sorghum bicolor L. Moench), wheat and soybean rotation (NT-RW; Glycine $\max$ L. Merr), and (4) conventional till, sorghum, wheat, and soybean rotation (CT-RW). For the CW plots, wheat was planted in $0.18-\mathrm{m}$ wide rows at ca. $9.3 \mathrm{~g} \mathrm{~m}^{-2}$ in early November each year and harvested every May. For the RW plots, sorghum was planted first in $1 \mathrm{~m}$ wide rows at ca. 18 seeds m-2 in March and harvested in late July/early August. This was followed by the same wheat planting scheme from the CW plots. Soybean was planted in 1-m wide rows at 122 ca. 23 seeds m-2 in early June and harvested in October after the wheat harvest. Conventional tillage was conducted by disking $(10-15 \mathrm{~cm})$ after harvest, followed by chisel-plowing $(20-25 \mathrm{~cm})$, a second disking, and ridging before winter. For the no-till plots, the soil was not disturbed except for banded fertilizer applications for sorghum and planting of crops.

Treatments are replicated four times in a randomized complete block design for a total of sixteen plots $(12 \mathrm{~m} \times$ $4 \mathrm{~m}$ ), and composite soil samples were collected from each plot (25-30 soil cores per plot; $2 \mathrm{~cm}$ diameter cores, 0$5 \mathrm{~cm}$ depth). Continuous wheat treatments received annual broadcasted treatments of $68 \mathrm{~kg} \mathrm{Nha}^{-1}\left(\mathrm{NH}_{4} \mathrm{NO}_{3}\right)$, while RW plots received $68 \mathrm{~kg} \mathrm{Nha}^{-1}$ for wheat, $90 \mathrm{~kg} \mathrm{Nha}^{-1}$ for sorghum, and no $\mathrm{N}$ fertilizer for soybean. Soil cores were collected at the beginning of wheat growth in the continuous wheat treatments and following sorghum. Samples were taken in November 2007 during a very early vegetative stage of wheat growth. The soil samples were characterized for various physical, chemical, and microbial properties as reported by González-Chávez et al. [26].

2.2. Soil DNA Extraction. For qPCR assays, approximately $10 \mathrm{~g}$ of soil from three replicate plots per treatment were extracted using a PowerMax Soil DNA Isolation Kit (Mo Bio Laboratories, Carlsbad, CA, USA) according to the manufacturer's instructions. DNA samples were purified using a $1.2 \%$ low-melting-point agarose gel and then extracted using a Wizard SV gel and PCR clean up kit (Promega, Madison, WI, USA). Following purification, the microbial community DNA samples were quantified using a Nanodrop ND-100 spectrophotometer (Nanodrop Technologies, Wilmington, DE, USA). For 16S rRNA gene libraries, approximately $2.5 \mathrm{~g}$ of soil from each of the four treatment replicates were combined to create a $10 \mathrm{~g}$ composite soil sample for each of the tillage/crop-rotation treatments. Community DNA was extracted from each of the composite soil samples using an UltraClean Mega Soil DNA Isolation Kit (Mo Bio) according 
to the manufacturer's instructions and purified as described above for the qPCR assays.

2.3. Bacterial and Fungal Quantitative PCR. Community qPCR assays, based upon Fierer et al. [29], were used to evaluate the relative abundance of bacteria and fungi in our soil samples. The qPCR reactions $(10 \mu \mathrm{L}$ total reaction volume) were performed in triplicate. The reaction mixtures contained $4.5 \mu \mathrm{L} 2 \mathrm{x}$ SYBR Green mix (5 Prime, Inc., Gaithersburg, MD, USA), $0.5 \mu \mathrm{L}$ of each primer $(10 \mu \mathrm{M})$, $1.0 \mu \mathrm{L}$ BSA $\left(10 \mathrm{mg} \mathrm{mL}^{-1}\right), 2.5 \mu \mathrm{L}$ molecular grade water, and $1.0 \mu \mathrm{L}$ template DNA $\left(2.5 \mathrm{ng} \mu \mathrm{L}^{-1}\right.$ for all reactions other than the plasmid standards). Primer set Eub338/518, as described by Fierer et al. [29], was used for bacteria, and primer set 5.8S/ITS1F, as described by Boyle et al. [30], was used for fungi. Reaction plates were prepared using a CAS-1200 PCR robot (Qiagen, Germantown, MD, USA), and amplification was conducted using a Mastercycler ep realplex thermal cycler (Eppendorf, Hamburg, Germany). The amplification conditions for both the bacterial and fungal assays consisted of $95^{\circ} \mathrm{C}$ for $15 \mathrm{~min}$ followed by 40 cycles of $95^{\circ} \mathrm{C}$ for $1 \mathrm{~min}, 53^{\circ} \mathrm{C}$ for $30 \mathrm{sec}$, and $72^{\circ} \mathrm{C}$ for $1 \mathrm{~min}$ with fluorescence captured after the $72^{\circ} \mathrm{C}$ step.

Plasmid standards for the $16 \mathrm{~S}$ rRNA and ITS reactions were constructed using the genomic DNA of Escherichia coli DH10B (pUC19) (obtained from Dr. Carlos Gonzales, Department of Plant Pathology, Texas A\&M University) and Neurospora crassa 74-OR23-1VA (obtained from Dr. Heather Wilkinson, Department of Plant Pathology, Texas A\&M University). Target gene fragments were amplified from the E. coli and N. crassa using a FailSafe PCR kit (Epicenter Biotechnologies, Madison, WI, USA), their corresponding $\mathrm{QPCR}$ primer sets, and the amplification conditions described above. Each $25 \mu \mathrm{L}$ PCR reaction contained $0.25 \mu \mathrm{L}$ forward primer $(10 \mu \mathrm{M}), 0.25 \mu \mathrm{L}$ of reverse primer $(10 \mu \mathrm{M})$, $1.25 \mathrm{U}$ Taq polymerase (Fisher Scientific, Pittsburgh, PA, USA), $10.75 \mu \mathrm{L}$ molecular grade water, $12.50 \mu \mathrm{L} 2 \mathrm{x}$ Failsafe buffer E (Epicentre Biotechnologies), and 50 ng template DNA. The gene fragments were cloned into a pGEM-T easy cloning kit (Promega), and plasmids from successful transformants were extracted using a Wizard SV Miniprep kit (Promega). The extracted plasmids were normalized to a concentration of $0.5 \mathrm{ng} \mu \mathrm{L}^{-1}$ and were used as a dilution series $\left(10^{-1}, 10^{-3}, 10^{-5}\right.$, and $\left.10^{-7}\right)$ to construct standard curves. Concentrations of DNA were converted to copy numbers of genes as described by Smits et al. [31].

2.4. $16 S$ rRNA Gene Sequencing. The 16S rRNA genes were amplified from community DNA using primers $27 \mathrm{~F}$ and 1492R [32]. Each $25 \mu \mathrm{L}$ reaction contained $30 \mathrm{ng}$ template DNA, $12.5 \mu \mathrm{L} 2 \mathrm{x}$ FailSafe buffer E (Epicentre Biotechnologies), $1.25 \mathrm{U} \mathrm{Taq}$ polymerase (Fisher Scientific), $9 \mu \mathrm{L}$ molecular grade water, and $0.5 \mu \mathrm{L}$ of each primer $(10 \mu \mathrm{M})$. Amplification was conducted in a Mastercycler ep thermal cycler (Eppendorf) under the following conditions: (i) initial denaturation at $95^{\circ} \mathrm{C}$ for $1 \mathrm{~min}$; (ii) 30 cycles of denaturation at $94^{\circ} \mathrm{C}$ for $1 \mathrm{~min}$, annealing at $55^{\circ} \mathrm{C}$ for $1 \mathrm{~min}$, and extension at $72^{\circ} \mathrm{C}$ for $1 \mathrm{~min}, 30 \mathrm{sec}$; (iii) a final extension at $72^{\circ} \mathrm{C}$ for $7 \mathrm{~min}$. Five replicate amplifications were performed for each sample, and their products were combined for all downstream applications [33].

PCR products were confirmed for size using a $1.2 \%$ $(\mathrm{w} / \mathrm{v})$ low-melting-point agarose gel and UV light. Product bands ( $\sim 1500 \mathrm{bp})$ were excised from the gel and purified using a Wizard SV gel and PCR clean-up kit (Promega). The purified PCR products were then cloned into a pGEMT Easy kit (Promega). Approximately 300 positive clones were selected from each sample, transferred to 96-well plates containing LB-ampicillin broth $\left(50 \mu \mathrm{g} \mathrm{mL}^{-1}\right.$ ampicillin), and incubated for an additional $12 \mathrm{~h}$. Glycerol stocks of each clone were submitted to Agencourt Bioscience Corporation (Beverly, MA, USA) for single-pass sequencing with primer 27F.

2.5. 16S rRNA Gene Sequence and Statistical Analyses. The $16 \mathrm{~S}$ sequences were quality-checked and edited using Sequencher, v4.2 (Gene Codes Corporation, Ann Arbor, MI, USA). Sequences were screened for chimeras using Bellerophon [34], and all potential chimeras were excluded from further analysis. Nonchimeric sequences were aligned using the Ribosomal Database Project's (RDP) Aligner tool and assigned putative identities with RDP Classifier [35]. The aligned sequences were trimmed to a common length, and distance matrices were then calculated using the DNAdist program in PHYLIP [36].

The MOTHUR software package (version 1.14) [37] was used to assign sequences to operational taxonomic units (OTUs, 97\% similarity) and calculate diversity indices and richness estimators. MOTHUR's dist. shared function was used to calculate Yue-Clayton similarity values $\left(\theta_{\mathrm{YC}}\right)$, which describe the degree of overlap shared among the 4 communities and were used as the basis for cluster analysis. In addition, MOTHUR's clearcut [38] and parsimony functions were used to generate a study-wide neighborjoining phylogenetic tree and perform parsimony analysis [39]. The parsimony test compares phylogenetic structure among and between communities and evaluates the degree to which differences (or similarities) in community structure may be attributed to random variation (i.e., by chance) or other factors (e.g., management practices). Analogous to ANOVA, pairwise comparisons are only performed if a statistically significant result is detected at the whole-study level first. $P$-values $\leq 0.05$ were considered to be statistically significant at the whole-study level, and a Bonferroni correction for multiple comparisons adjusted this value to $P \leq 0.0083$ for the pairwise comparisons. And finally, the RDP's Library Compare tool [40] was used to pinpoint which taxonomic groups might underlie differences in community structure.

Bacterial and fungal copy numbers were compared across treatments using one-way ANOVA, and posthoc comparisons were made using the Bonferroni correction for multiple comparisons. All comparisons were performed using SPSS (version 15.0). Gene copy number values, as well as the relative abundances of various bacterial taxa were compared with soil chemical and physical data, as well as FAME values from González-Chávez et al. [26] using regression analysis in Microsoft Excel 2007. 


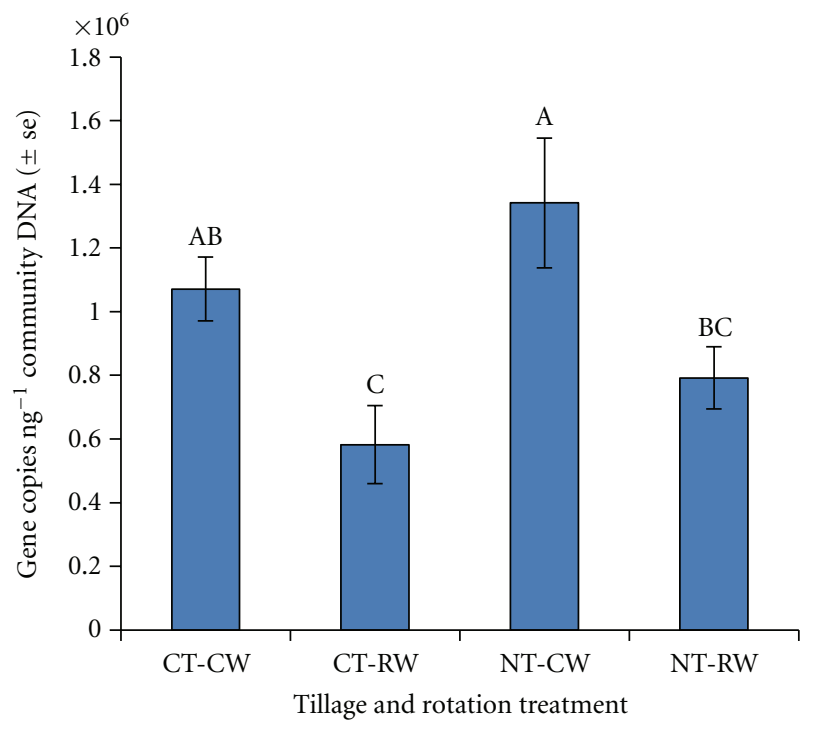

(a) Bacterial $16 \mathrm{~S}$ copies

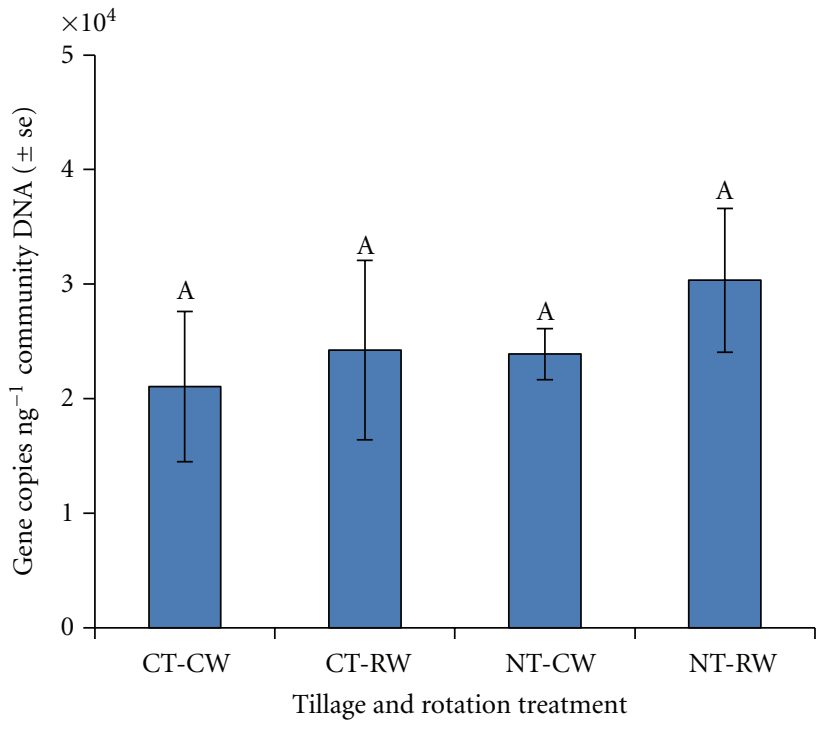

(b) Fungal ITS copies

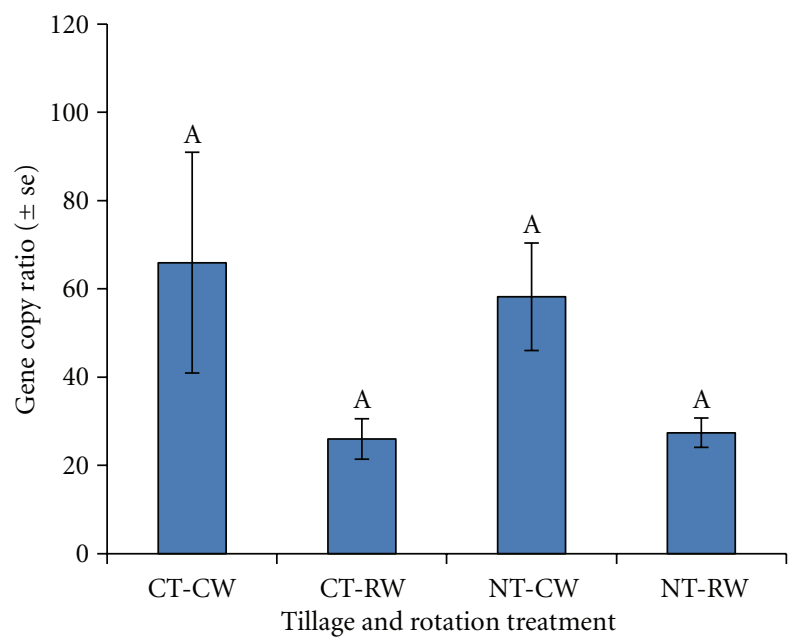

(c) Bacterial to fungal ratio

FIGURE 1: Abundance of bacteria (a) and fungi (b) along with bacterial : fungal ratios (c), as determined by qPCR, in soil under different longterm tillage and rotation treatments. Error bars represent \pm standard error of three replicate samples. NT: no tillage; CT: conventional tillage; CW: continuous wheat; RW: sorghum-wheat-soybean rotation. Different uppercase letters above bars within a figure indicate significant differences at $P=0.05$.

The 16S rRNA sequences used in this study were submitted to NCBI GenBank under accession numbers GU908521GU909443.

\section{Results}

3.1. Bacterial and Fungal Quantitative PCR. Bacterial copy numbers were significantly higher in NT plots with CW than with RW and showed a decreasing, but not significant, trend in plots with CT (Figure 1). NT-CW and NT-RW plots had $16 \mathrm{~S}$ rRNA copy numbers that averaged $1.3 \times 10^{6}$ and $7.9 \times$ $10^{5} \mathrm{ng}^{-1}$ of DNA, respectively, compared to $1.1 \times 10^{6}$ and $5.8 \times 10^{5}$ copies in CT-CW and CT-RW plots, respectively. Fungal copy numbers ranged from $2.1 \times 10^{4}$ to $3.0 \times 10^{4}$ ITS copies $\mathrm{ng}^{-1}$ of community DNA in the various treatments. A slight trend toward decreasing ITS copy number was observed in CT plots, but treatment differences were not significant. The ratios of bacterial to fungal copy numbers appeared to trend higher, but were not significantly different, in CW (62) compared to RW plots (27.5). Additionally, there were no significant differences between the average bacterial : fungal ratios of NT (42.5) and CT plots (46).

Relative bacterial abundance, as determined by qPCR, had a strong positive correlation with the abundance of bacterial FAMEs $\left(r^{2}=0.81\right)$ [26], but poor correlation was observed between relative fungal abundance (qPCR) and fungal FAMEs $\left(r^{2}=0.05\right)$ or the bacterial: fungal ratios determined by qPCR and FAME procedures $\left(r^{2}=0.36\right)$. 
TABLE 1: Summary of bacterial operational taxonomic unit (OTU) richness and diversity estimates in soil under different long-term tillage and rotation treatments.

\begin{tabular}{lcccc}
\hline Treatment & $\begin{array}{c}\text { Sequence } \\
\text { library size }\end{array}$ & $\begin{array}{c}\text { Number of } \\
\text { OTUs } \\
\text { detected }\end{array}$ & $\begin{array}{c}\text { Shannon's } \\
\text { diversity } \\
\left(H^{\prime}\right)\end{array}$ & $\begin{array}{c}\text { Chao I } \\
\text { richness }\end{array}$ \\
\hline CT-CW & 236 & 177 & 5.06 & 527 \\
CT-RW & 234 & 155 & 4.86 & 381 \\
NT-CW & 225 & 166 & 4.96 & 584 \\
NT-RW & 228 & 165 & 4.91 & 577 \\
\hline Total & 923 & 541 & - & - \\
\hline
\end{tabular}

${ }^{a}$ NT: no tillage; CT: conventional tillage; CW: continuous wheat; RW: sorghum-wheat-soybean rotation.

3.2. Bacterial Community Composition. Shannon's diversity index values were slightly higher in CW than RW samples, and no consistent differences were observed with respect to tillage treatment (Table 1). In contrast, richness estimates were higher in NT than CT samples, but there were not consistent differences in comparison with the rotation. The CT-RW treatment combination resulted in both the lowest diversity and richness estimates.

At the phylum level, soil bacterial communities from the different treatments were similar to one another in terms of community composition (Table 2). Members of the Acidobacteria and Proteobacteria accounted for 67 to $72 \%$ of all clones from each tillage and crop-rotation treatment. Other phyla detected included Actinobacteria, Planctomycetes, Bacteroidetes, Firmicutes, Cyanobacteria, Verrucomicrobia, and Gemmatimonadetes.

Despite the high degree of similarity shared among the communities at the phylum level, differences among the treatments became more apparent when phylogenetic structure (using the parsimony test) and OTU-level composition (using $\theta_{\mathrm{YC}}$ ) were examined. The parsimony test found statistically significant differences among the crop rotation and tillage treatment communities. More specifically, the parsimony test found that the CT-CW community differed significantly different with those from the NT-RW and CTRW treatments. Although the parsimony test and clustering techniques that we used are not necessarily synonymous with one another, this pattern can also be seen in the clustering of the communities in the dendrogram shown in Figure 2. The two RW treatments (CT-RW and NT-RW) shared $>33 \%$ of their community structure (in terms of OTU occurrence and relative abundances) and clustered more closely with one another than they did with the two CW treatments (CT-CW and NT-CW) (Figure 2).

Lending additional support to these results, RDP's Library Compare tool detected significant differences in the proportions of Cyanobacteria, Actinobacteria, and Firmicutes in the various treatments, as compared to CT-CW. Cyanobacteria were less abundant under CT-RW than CTCW. In contrast, Actinobacteria were more abundant under CT-RW than CT-CW, largely due to increased populations of Rubrobacter spp. (see Table 1, Supplementary Material available online at doi:10.5402/2012/487370). Firmicutes
TABle 2: Pairwise comparison of treatments and comparison of phylogenetic groups between treatments. (A) Parsimony test results between treatments. (B) Relative abundances of bacterial phyla detected in 16S rRNA gene clone libraries derived from soil under different long-term tillage and rotation treatments.

\begin{tabular}{|c|c|c|c|c|}
\hline \multirow{2}{*}{ Phylogenetic group } & \multicolumn{4}{|c|}{ Treatment $^{\mathrm{a}}$} \\
\hline & CT-CW & CT-RW & NT-CW & NT-RW \\
\hline \multicolumn{5}{|l|}{ (A) Treatment } \\
\hline CT-CW & - & & & \\
\hline CT-RW & $<0.001$ & - & & \\
\hline NT-CW & 0.083 & 0.109 & - & \\
\hline NT-RW & 0.007 & 0.028 & 0.086 & - \\
\hline (B) Phylogenetic group & \multicolumn{4}{|c|}{$\%$} \\
\hline Acidobacteria & 44.1 & 43.6 & 48.0 & 46.9 \\
\hline Actinobacteria & 5.9 & $9.4^{*}$ & 3.6 & 7.5 \\
\hline Bacteroidetes & 6.4 & 5.6 & 4.0 & 3.1 \\
\hline Chloroflexi & nd & nd & nd & 0.4 \\
\hline Cyanobacteria & 3.0 & $0.4^{*}$ & 4.4 & 1.3 \\
\hline Deinococcus-Thermus & nd & nd & nd & 0.4 \\
\hline Firmicutes & 3.8 & 2.1 & $0.9^{*}$ & 1.3 \\
\hline Gemmatimonadetes & 2.5 & 1.3 & 1.3 & 0.9 \\
\hline Nitrospira & 0.4 & nd & nd & nd \\
\hline OP10 & 0.8 & nd & nd & 0.4 \\
\hline OP11 & nd & 0.4 & nd & nd \\
\hline Planctomycetes & 4.7 & 4.3 & 4.9 & 5.3 \\
\hline Proteobacteria & 22.9 & 27.4 & 24.4 & 22.4 \\
\hline$\alpha$-Proteobacteria & 5.5 & 10.3 & 5.3 & 6.1 \\
\hline$\beta$-Proteobacteria & 8.5 & 8.1 & 10.7 & 8.8 \\
\hline$\gamma$-Proteobacteria & 4.7 & 3.0 & 4.4 & 2.6 \\
\hline$\delta$-Proteobacteria & 4.2 & 6.0 & 4.0 & 4.8 \\
\hline TM7 & 0.4 & nd & nd & nd \\
\hline Verrucomicrobia & 1.7 & 1.3 & 1.3 & 1.8 \\
\hline WS3 & 0.4 & nd & nd & nd \\
\hline Unclassified bacteria & 3.0 & 4.3 & 7.1 & 8.3 \\
\hline
\end{tabular}

${ }^{a} \mathrm{NT}$ : no tillage; CT: conventional tillage; CW: continuous wheat; RW: sorghum-wheat-soybean rotation.

nd indicates that the phylogenetic group was not detected.

${ }^{*}$ Significantly different from CT-CW at $P: 0.05$.

were less abundant under NT-CW than CT-CW, largely due to decreased abundances of Bacillus spp. (Suppl. Table 1).

3.3. Correlation of Microbial Populations with Soil Properties. Strong correlations were observed between certain bacterial phyla and several soil parameters, including $\mathrm{pH}$, organic $\mathrm{C}$ (OC), total $\mathrm{N}(\mathrm{TN})$, and microbial biomass $\mathrm{C}, \mathrm{N}$, and $\mathrm{P}$ (Table 3). The Acidobacteria and Planctomycetes tended to be positively correlated with pools of soil and microbial biomass $\mathrm{C}$ and $\mathrm{N}\left(r^{2}=0.63\right.$ to 0.99$)$. In contrast, Bacteroidales were negatively correlated with soil and microbial $\mathrm{C}$ and $\mathrm{N}\left(r^{2}=\right.$ 0.77 to 0.99 ), while Acidobacteria were negatively correlated with $\mathrm{pH}\left(r^{2}=0.94\right)$. The relative abundance of fungi was positively correlated with microbial biomass $\mathrm{C}, \mathrm{N}$, and $\mathrm{P}$ $\left(r^{2}=0.69,0.59\right.$, and 0.58 , resp. $)$, but neither the relative 


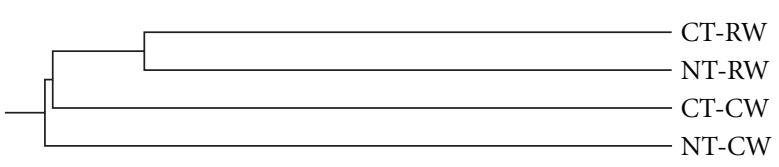

0.1

Figure 2: Cluster analysis of bacterial community structure under different long-term tillage and crop rotation treatments. Branch lengths illustrate dissimilarity values (1-Yue-Clayton similarity), with shorter branch lengths representing greater levels of similarity and longer branch lengths representing increasing dissimilarity. NT: no tillage; CT: conventional tillage; CW: continuous wheat; RW: sorghum-wheat-soybean rotation.

abundance of bacteria, nor the ratio of bacteria to fungi was correlated strongly with any of the pools of $\mathrm{C}$ and $\mathrm{N}$.

\section{Discussion}

4.1. Bacterial and Fungal Quantitative PCR. Bacterial $\mathrm{qPCR}$ indicated that relative bacterial numbers were greater in CW compared to RW treatments, while tillage had little effect on bacterial abundances. In contrast, no treatment had a clear impact on fungal relative abundances (Figure 1). While many studies indicate that no-till practices can lead to increased soil fungal population levels, other studies have reported that no-till stimulates both bacterial and fungal populations [27, 41]. Allison et al. [27] reported that conversion of land from conventional tillage agriculture to tallgrass prairie initially increased the fungal:bacterial ratio, ostensibly due to reduced disturbance from tilling, but that the fungal:bacterial ratio decreased over time. Helgason et al. [12] also found increased levels of bacteria and fungi in no-till soils, but there was not a clear pattern in fungal:bacterial ratios. While these differences could be related to the use of different methods (e.g., PLFA versus $\mathrm{qPCR}$ ), they might also be influenced by the specific cropping sequence and the timing of sample collection [42]. Our results indicate that crop rotation (continuous wheat versus the sorghum-wheat-soybean rotation) had a larger impact on relative bacterial abundance and bacterial: fungal ratios than did tillage practices. The soil samples used in this experiment were collected two months after wheat was sown and four months after sorghum residue was incorporated. If the soil samples had been collected at a different time point (e.g., when both plots were not sown in wheat), we might have observed a greater rotational effect on bacterial and fungal relative abundances. Similarly, if soil samples had been collected closer to the tillage event (e.g., 2 days after tillage), then we might have observed a greater tillage effect on bacterial: fungal ratios.

The results for the relative abundance of bacteria and fungi, as determined using $\mathrm{qPCR}$ in this study, differed somewhat from those previously published for these same samples, which were determined using FAME analysis [26]. While there was good correlation between the qPCR- and FAME-derived bacterial data, the fungal results from the two methods were only weakly correlated. This is likely due to the limited number of fungal biomarkers used in the FAME analysis and/or biases in our PCR primers. In any case, this highlights the need for using multiple methods for microbial analysis that complement potential limitations of the other $\operatorname{method}(\mathrm{s})$.

Although the relative bacterial and fungal numbers, as determined by qPCR, were not significantly different in the NT compared to the CT plots, the total numbers would likely be higher for both bacteria and fungi in the NT plots. The qPCR results in our study are presented as a proportion of the total community (i.e., per ng DNA) and not on a quantitative basis (i.e., per gram of soil). Since the microbial biomass was $\geq 70 \%$ higher in the NT than CT plots [26], the small differences in relative population size detected with $\mathrm{QPCR}$ are likely to represent much greater differences when considered for the total microbial community on a quantitative basis. In order to examine this possibility, our results were converted to a semiquantitative basis by multiplying the qPCR data by the microbial biomass $\mathrm{C}$ data for the different treatments [26]. The semiquantitative rankings of the bacterial populations among the various treatments were NT-CW $>$ NT-RW $>$ CT-CW $>$ CT-RW and the fungal populations were NT-RW $>$ NT-CW $>$ CT-RW $>$ CT-CW (data not shown). These results suggest that bacterial and fungal populations were both higher in the NT than the CT soils, which would agree with results published by other researchers $[12,40]$.

4.2. Bacterial Community Composition. Similar to the qPCR results, the $16 \mathrm{~S}$ rRNA sequencing indicated that cropping sequence had a larger impact on bacterial community composition than did tillage practice (Figure 2). Bacterial diversity was slightly higher in CW than RW plots, but there was no clear trend with respect to diversity among tillage treatments. Bacterial richness, however, was higher in soil from NT plots compared to CT plots. GonzálezChávez et al. [26] reported a similar trend for microbial richness in these soils using FAME analysis. Similar results were also found by Upchurch et al. [7], who also found no change in diversity, but did observe increasing bacterial richness resulting from no-till treatments. In contrast, Acosta-Martínez et al. [28] found that transition from a continuous cotton system to a cotton-wheat-corn rotation, pasture, or Conservation Resource Program (CRP) altered soil bacterial communities with greater species richness being detected in the continuous cotton and cotton-wheat-corn rotation than in the pasture or CRP treatments. Interestingly, conversion of continuous cotton to the untilled treatments (pasture and CRP) appeared to result in greater changes to bacterial community composition than the transition to the cotton-wheat-corn rotation. However, the cotton-wheatcorn rotation plots had only been established for $\sim 3 \mathrm{yrs}$, and it is difficult to distinguish between the effects of reduced tillage and crop/plant species since the same crop was not planted in both tilled and untilled plots.

At the phylum level, bacterial community composition was very similar in all treatments, in that each treatment was dominated by Acidobacteria and Proteobacteria (Table 2). 


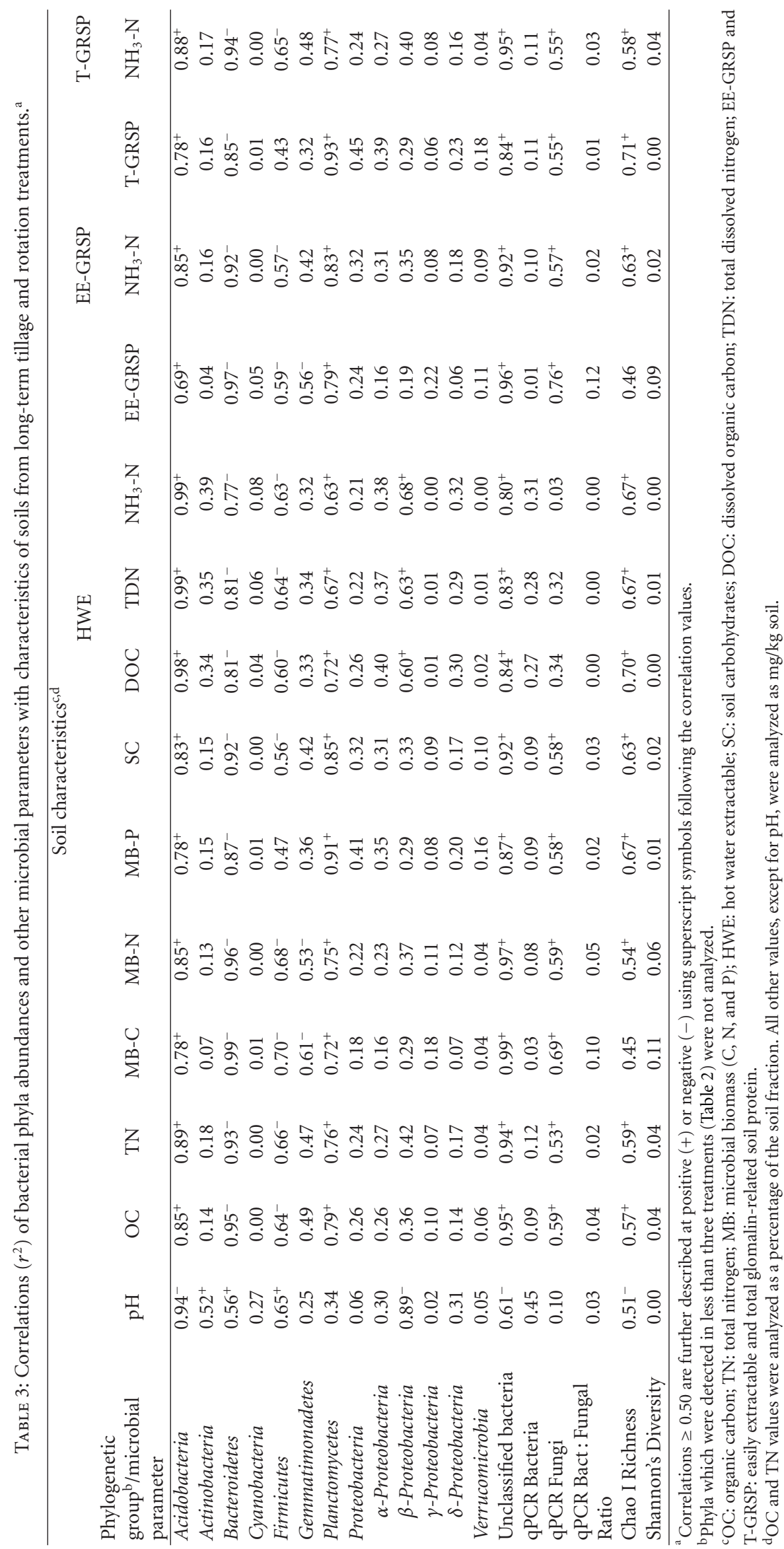


However, significant differences were detected among the communities with respect to their phylogenetic structure(s), and these differences may be related to varying abundances among some less-dominant bacterial populations. For example, Cyanobacteria were more abundant in the CT-CW plots than in the CT-RW plots, and a similar, though not significant, relationship was observed between the NT-CW and NT-RW plots. The increased level of Cyanobacteria in the CW treatments was likely due to the longer unplanted period between crops. The CW plots are typically harvested in midMay and are not planted again until the next November. The RW plots would have sorghum planted in March and harvested in late July/early August, followed by wheat planted in November. Therefore, CW plots would have a longer fallow period between plantings than the RW treatment, providing a longer window during which the soil surface would receive sunlight and thus stimulate photosynthetic organisms such as Cyanobacteria [43]. Another possible explanation is that some populations of Cyanobacteria may have been more adept at colonizing the rhizosphere of wheat and, thus, proliferated in the CW treatments [44].

Compared to the CT-CW plots, Actinobacteria were more abundant in the CT-RW plots (Table 2). Although other researchers have reported slight increases in Actinobacteria populations in no-till soil [7], the increased Actinobacteria populations in our study appear to be due to crop rotation. Actinobacteria are important in the cycling of organic materials such as cellulose and their relative abundances may have been increased in the RW treatments due to the incorporation of sorghum residue during the previous crop of cycle rotation [45]. Many of these Actinobacteria were classified as Rubrobacter spp. and were similar to clones found by other researchers in arid soils around the world [46]. Of the additional Firmicutes in the CT-CW soil relative to the NT-CW soil, many were classified as Bacillus spp. This phylogenetic group represents a very diverse set of bacteria that includes both aerobic and facultative anaerobic organisms [47]. Therefore, it appears that tillage rather than rotation was responsible for the lower populations of Firmicutes, and it is difficult to discern the precise reason(s) for this shift in community composition.

4.3. Correlation of Microbial Populations with Soil Properties. Although bacterial copy numbers generally did not correlate well with soil chemical and physical properties, there were strong correlations between several bacterial populations and soil properties (Table 3). Populations of Acidobacteria were negatively correlated with $\mathrm{pH}$. Furthermore, Acidobacteria and Planctomycetes tended to be positively correlated with various pools of soil and microbial biomass $\mathrm{C}$ and $\mathrm{N}$ while Bacteroidales were negatively correlated with these factors. As the name implies, Acidobacteria tend to be acidophilic and are often found to be strongly negatively correlated with soil $\mathrm{pH}$ [48]. It is not surprising, then, that we found Acidobacteria to be negatively correlated with $\mathrm{pH}$ here as well. It has been argued that Acidobacteria tend to be oligotrophic and that Bacteroidetes tend to be copiotrophic, meaning that populations of Acidobacteria have an inverse relationship with $\mathrm{C}$ mineralization in contrast to Bacteroidetes which have a positive relationship with $\mathrm{C}$ mineralization [49]. Interestingly, our results appear to be the opposite of this previous observation. While we did not measure $\mathrm{C}$ mineralization directly, microbial biomass $\mathrm{C}$ and various pools of hot-water extractable $\mathrm{C}$, which would be a measure of potentially labile $\mathrm{C}$, were quantified in the study of González-Chávez et al. [26]. Additionally, previous studies have shown that mineralized $\mathrm{C}$ levels were higher in NT than CT plots at this site [50] and that there is a strong correlation between mineralization rates and microbial biomass [51]. As this indirect relationship appears to conflict with previous literature, further analysis linking specific phyla with functional data should be a goal of future research. Both Acidobacteria and Bacteroidetes are very broad phyla so it is possible that our soil selected for populations different than those in the samples examined by Fierer et al. [49].

The strong correlation of Planctomycetes with various pools of soil and microbial biomass $\mathrm{C}$ and $\mathrm{N}$ is of particular interest since several Planctomycetes are responsible for the anaerobic oxidation of ammonium (ANAMMOX). Recent studies are just beginning to characterize the ubiquity of these organisms and ANAMMOX in soil environments [5254]. Although most of the Planctomycetes in this study were more similar to those known to be heterotrophic bacteria instead of those involved in ANAMMOX, several of the sequences had relatively low matches at the genus level to previously characterized microorganisms and thus were grouped as unclassified bacteria. The closest matches in public databases (e.g., GenBank) to many of these were Planctomycetes. The strong correlation of Planctomycete populations with many of the soil properties associated with the NT plots along with the limited understanding of the ecological role of these organisms suggests that additional studies should be conducted in order to further examine the importance of ANAMMOX in agricultural and especially notill systems. The good correlation between some bacterial groups with GRSP also deserves more studies because these proteins have been related to important soil processes (soil aggregation and $\mathrm{C}$ sequestration), and there is little knowledge regarding arbuscular mycorrhizal byproducts interacting with soil bacteria.

\section{Conclusion}

Our results indicate that long-term tillage practices and cropping rotations can impact soil microbial populations, diversity, richness, and community composition. Interestingly, cropping sequence had a larger impact on bacterial community composition and relative levels of bacteria and fungi than did the tillage treatment. However, this experiment only analyzed samples from one time point, when all treatments were planted in wheat. Future experiments should also consider analyzing samples over an extended period of time in order to gain a better understanding of microbial dynamics in response to the different crops in the rotation system. It is somewhat surprising that the notill practice appeared to have a limited impact on microbial community composition. It is possible that additional 
sequencing of the bacterial community in addition to fungal and archaeal sequencing would reveal further differences. It should also be noted that the bacterial characterization in this study, based upon 16S rRNA sequencing, determined bacterial taxonomy and that microbial function was inferred by comparison against similar bacteria which have been isolated and characterized. However, bacteria with very similar 16S rRNA genes can have very different functional capabilities and there are several groups of microorganisms for which there are no or only a limited number of cultured representatives to use for comparison. Therefore, additional differences in community composition and function may have been present that were not detected with the methods used in this experiment. Future work should strive to also characterize soils using additional sequencing approaches (e.g., metagenomic sequencing) and/or functional gene assays. Efforts should also be continued to isolate and characterize novel microorganisms, such as the Planctomycetes, in order to determine their potential ecological function. Ultimately, this information will aid the continued development of sustainable management of agricultural ecosystems.

\section{Abbreviations}

qPCR: quantitative Polymerase Chain Reaction

16S rRNA: $16 \mathrm{~S}$ ribosomal ribonucleic acid

NT: $\quad$ No till

CT: Conventional till

CW: Continuous wheat

RW: $\quad$ Sorghum, wheat and soybean rotation

GRSP: Glomalin-related soil proteins

BSA: Bovine serum albumin.

\section{Acknowledgments}

Support for this research was provided by CONACyT (Sabbatical Leave-CGC) and Texas AgriLife Research. This study is a publication of Texas AgriLife Research Hatch Project TEX09194 (JAAP) and TEX08174 (FMH). The funding organizations were not involved in designing or conducting this research.

\section{References}

[1] D. H. Buckley and T. M. Schmidt, "The structure of microbial communities in soil and the lasting impact of cultivation," Microbial Ecology, vol. 42, no. 1, pp. 11-21, 2001.

[2] A. J. Franzluebbers, F. M. Hons, and V. A. Saladino, "Sorghum, wheat and soybean production as affected by long-term tillage, crop sequence and N fertilization," Plant and Soil, vol. 173, no. 1, pp. 55-65, 1995.

[3] Y. Feng, A. C. Motta, D. W. Reeves, C. H. Burmester, E. van Santen, and J. A. Osborne, "Soil microbial communities under conventional-till and no-till continuous cotton systems," Soil Biology \& Biochemistry, vol. 35, no. 12, pp. 1693-1703, 2003.

[4] S. D. Frey, T. Elliott, and K. Paustian, "Bacterial and fungal abundance and biomass in conventional and no-tillage agroecosystems along two climatic gradients," Soil Biology \& Biochemistry, vol. 31, no. 4, pp. 573-585, 1999.
[5] L. Øvreås and V. Torsvik, "Microbial diversity and community structure in two different agricultural soil communities," Microbial Ecology, vol. 36, no. 3, pp. 303-315, 1998.

[6] M. C. Ferreira, D. S. Andrade, L. M. O. Chueire, S. M. Takemura, and M. Hungria, "Tillage method and crop rotation effects on the population sizes and diversity of bradyrhizobia nodulating soybean," Soil Biology \& Biochemistry, vol. 32, no. 5, pp. 627-637, 2000.

[7] R. Upchurch, C. Y. Chiu, K. Everett, G. Dyszynski, D. C. Coleman, and W. B. Whitman, "Differences in the composition and diversity of bacterial communities from agricultural and forest soils," Soil Biology \& Biochemistry, vol. 40, no. 6, pp. 1294-1305, 2008.

[8] Z. Kabir, I. P. O’Halloran, J. W. Fyles, and C. Hamel, “Seasonal changes of arbuscular mycorrhizal fungi as affected by tillage practices and fertilization: hyphal density and mycorrhizal root colonization," Plant and Soil, vol. 192, no. 2, pp. 285-293, 1997.

[9] A. Mozafar, T. Anken, R. Ruh, and E. Frossard, "Tillage intensity, mycorrhizal and nonmycorrhizal fungi, and nutrient concentrations in maize, wheat, and canola," Agronomy Journal, vol. 92, no. 6, pp. 1117-1124, 2000.

[10] L. Galvez, D. D. Douds, L. E. Drinkwater, and P. Wagoner, "Effect of tillage and farming system upon VAM fungus populations and mycorrhizas and nutrient uptake of maize," Plant and Soil, vol. 228, no. 2, pp. 299-308, 2001.

[11] Z. Kabir, "Tillage or no-tillage: impact on mycorrhizae," Canadian Journal of Plant Science, vol. 85, no. 1, pp. 23-29, 2005.

[12] B. L. Helgason, F. L. Walley, and J. J. Germida, "Fungal and bacterial abundance in long-term no-till and intensive-till soils of the Northern Great Plains," Soil Science Society of America Journal, vol. 73, no. 1, pp. 120-127, 2009.

[13] N. Z. Lupwayi, W. A. Rice, and G. W. Clayton, "Soil microbial diversity and community structure under wheat as influenced by tillage and crop rotation," Soil Biology \& Biochemistry, vol. 30, no. 13, pp. 1733-1741, 1998.

[14] G. Depret, S. Houot, M. R. Allard, M. C. Breuil, R. Nouaïm, and G. Laguerre, "Long-term effects of crop management on Rhizobium leguminosarum biovar viciae populations," FEMS Microbiology Ecology, vol. 51, no. 1, pp. 87-97, 2004.

[15] J. M. Meriles, S. V. Gil, C. Conforto et al., "Soil microbial communities under different soybean cropping systems: characterization of microbial population dynamics, soil microbial activity, microbial biomass, and fatty acid profiles," Soil and Tillage Research, vol. 103, no. 2, pp. 271-281, 2009.

[16] G. A. Hide and P. J. Read, "Effects of rotation length, fungicide treatment of seed tubers and nematicide on diseases and the quality of potato tubers," Annals of Applied Biology, vol. 119, no. 1, pp. 77-87, 1991.

[17] C. W. Honeycutt, W. M. Clapham, and S. S. Leach, "Crop rotation and $\mathrm{N}$ fertilization effects on growth, yield, and disease incidence in potato," American Potato Journal, vol. 73, no. 2, pp. 45-61, 1996.

[18] B. Govaerts, M. Mezzalama, K. D. Sayre et al., "Longterm consequences of tillage, residue management, and crop rotation on selected soil micro-flora groups in the subtropical highlands," Applied Soil Ecology, vol. 38, no. 3, pp. 197-210, 2008.

[19] M. Hungria, J. C. Franchini, O. Brandão-Junior, G. Kaschuk, and R. A. Souza, "Soil microbial activity and crop sustainability in a long-term experiment with three soil-tillage and two crop-rotation systems," Applied Soil Ecology, vol. 42, no. 3, pp. 288-296, 2009. 
[20] M. S. Girvan, J. Bullimore, J. N. Pretty, M. A. Osborn, and A. S. Ball, "Soil type is the primary determinant of the composition of the total and active bacterial communities in arable soils," Applied and Environmental Microbiology, vol. 69, no. 3, pp. 1800-1809, 2003.

[21] R. S. Peixoto, H. L. C. Coutinho, B. Madari et al., "Soil aggregation and bacterial community structure as affected by tillage and cover cropping in the Brazilian Cerrados," Soil and Tillage Research, vol. 90, no. 1-2, pp. 16-28, 2006.

[22] J. A. Ceja-Navarro, F. N. Rivera-Orduña, L. Patiño-Zúñiga et al., "Phylogenetic and multivariate analyses to determine the effects of different tillage and residue management practices on soil bacterial communities," Applied and Environmental Microbiology, vol. 76, no. 11, pp. 3685-3691, 2010.

[23] A. J. Franzluebbers, F. M. Hons, and D. A. Zuberer, “Tillageinduced seasonal changes in soil physical properties affecting soil $\mathrm{CO}_{2}$ evolution under intensive cropping," Soil and Tillage Research, vol. 34, no. 1, pp. 41-60, 1995.

[24] F. Dou, A. L. Wright, and F. M. Hons, "Sensitivity of labile soil organic carbon to tillage in wheat-based cropping systems," Soil Science Society of America Journal, vol. 72, no. 5, pp. 14451453, 2008.

[25] F. Dou, A. L. Wright, and F. M. Hons, "Dissolved and soil organic carbon after long-term conventional and no-tillage sorghum cropping," Communications in Soil Science and Plant Analysis, vol. 39, no. 5-6, pp. 667-679, 2008.

[26] M. D. C. A. González-Chávez, J. A. Aitkenhead-Peterson, T. J. Gentry, D. A. Zuberer, F. M. Hons, and R. Loeppert, "Soil microbial community, $\mathrm{C}, \mathrm{N}$, and $\mathrm{P}$ responses to long-term tillage and crop rotation," Soil and Tillage Research, vol. 106, no. 2, pp. 285-293, 2010.

[27] V. J. Allison, R. M. Miller, J. D. Jastrow, R. Matamala, and D. R. Zak, "Changes in soil microbial community structure in a tallgrass prairie chronosequence," Soil Science Society of America Journal, vol. 69, no. 5, pp. 1412-1421, 2005.

[28] V. Acosta-Martínez, G. Burow, T. M. Zobeck, and V. G. Allen, "Soil microbial communities and function in alternative systems to continuous cotton," Soil Science Society of America Journal, vol. 74, no. 4, pp. 1181-1192, 2010.

[29] N. Fierer, J. A. Jackson, R. Vilgalys, and R. B. Jackson, “Assessment of soil microbial community structure by use of taxonspecific quantitative PCR assays," Applied and Environmental Microbiology, vol. 71, no. 7, pp. 4117-4120, 2005.

[30] S. A. Boyle, R. R. Yarwood, P. J. Bottomley, and D. D. Myrold, "Bacterial and fungal contributions to soil nitrogen cycling under Douglas fir and red alder at two sites in Oregon," Soil Biology \& Biochemistry, vol. 40, no. 2, pp. 443-451, 2008.

[31] T. H. M. Smits, C. Devenoges, K. Szynalski, J. Maillard, and C. Holliger, "Development of a real-time PCR method for quantification of the three genera Dehalobacter, Dehalococcoides, and Desulfitobacterium in microbial communities," Journal of Microbiological Methods, vol. 57, no. 3, pp. 369-378, 2004.

[32] D. J. Lane, "16S/23S rRNA sequencing," in Nucleic Acid Techniques in Bacterial Systematics, E. Stackenbrandt and M. Goodfellow, Eds., pp. 115-157, John Wiley \& Sons, Chichester, UK, 1991.

[33] X. Qiu, L. Wu, H. Huang et al., "Evaluation of PCR-generated chimeras, mutations, and heteroduplexes with 16S rRNA gene-based cloning," Applied and Environmental Microbiology, vol. 67, no. 2, pp. 880-887, 2001.

[34] T. Huber, G. Faulkner, and P. Hugenholtz, "Bellerophon: a program to detect chimeric sequences in multiple sequence alignments," Bioinformatics, vol. 20, no. 14, pp. 2317-2319, 2004.
[35] J. R. Cole, B. Chai, R. J. Farris et al., "The ribosomal database project (RDP-II): introducing myRDP space and quality controlled public data," Nucleic Acids Research, vol. 35, supplement 1, pp. D169-D172, 2007.

[36] J. Felsenstein, PHYLIP (Phylogeny Inference Package) Version 3.6., Department of Genome Sciences, University of Washington, Seattle, Wash, USA, 2005.

[37] P. D. Schloss, S. L. Westcott, T. Ryabin et al., "Introducing mothur: open-source, platform-independent, communitysupported software for describing and comparing microbial communities," Applied and Environmental Microbiology, vol. 75, no. 23, pp. 7537-7541, 2009.

[38] L. Sheneman, J. Evans, and J. A. Foster, "Clearcut: a fast implementation of relaxed neighbor joining," Bioinformatics, vol. 22, no. 22, pp. 2823-2824, 2006.

[39] A. P. Martin, "Phylogenetic approaches for describing and comparing the diversity of microbial communities," Applied and Environmental Microbiology, vol. 68, no. 8, pp. 3673-3682, 2002.

[40] Q. Wang, G. M. Garrity, J. M. Tiedje, and J. R. Cole, "Naïve Bayesian classifier for rapid assignment of rRNA sequences into the new bacterial taxonomy," Applied and Environmental Microbiology, vol. 73, no. 16, pp. 5261-5267, 2007.

[41] P. M. White and C. W. Rice, "Tillage effects on microbial and carbon dynamics during plant residue decomposition," Soil Science Society of America Journal, vol. 73, no. 1, pp. 138-145, 2009.

[42] T. A. Spedding, C. Hamel, G. R. Mehuys, and C. A. Madramootoo, "Soil microbial dynamics in maize-growing soil under different tillage and residue management systems," Soil Biology \& Biochemistry, vol. 36, no. 3, pp. 499-512, 2004.

[43] E. M. Pankratova, "Functioning of Cyanobacteria in soil ecosystems," Eurasian Soil Science, vol. 39, supplement 1, pp. S118-S127, 2006.

[44] N. Karthikeyan, R. Prasanna, L. Nain, and B. D. Kaushik, "Evaluating the potential of plant growth promoting cyanobacteria as inoculants for wheat," European Journal of Soil Biology, vol. 43, no. 1, pp. 23-30, 2007.

[45] F. Bastian, L. Bouziri, B. Nicolardot, and L. Ranjard, "Impact of wheat straw decomposition on successional patterns of soil microbial community structure," Soil Biology \& Biochemistry, vol. 41, no. 2, pp. 262-275, 2009.

[46] A. J. Holmes, J. Bowyer, M. P. Holley, M. O’Donoghue, M. Montgomery, and M. R. Gillings, "Diverse, yet-to-be-cultured members of the Rubrobacter subdivision of the Actinobacteria are widespread in Australian arid soils," FEMS Microbiology Ecology, vol. 33, no. 2, pp. 111-120, 2000.

[47] N. Connor, J. Sikorski, A. P. Rooney et al., "Ecology of speciation in the genus Bacillus," Applied and Environmental Microbiology, vol. 76, no. 5, pp. 1349-1358, 2010.

[48] R. T. Jones, M. S. Robeson, C. L. Lauber, M. Hamady, R. Knight, and N. Fierer, "A comprehensive survey of soil acidobacterial diversity using pyrosequencing and clone library analyses," The ISME Journal, vol. 3, no. 4, pp. 442-453, 2009.

[49] N. Fierer, M. A. Bradford, and R. B. Jackson, "Toward an ecological classification of soil bacteria," Ecology, vol. 88, no. 6, pp. 1354-1364, 2007.

[50] A. J. Franzluebbers, F. M. Hons, and D. A. Zuberer, "Longterm changes in soil carbon and nitrogen pools in wheat management systems," Soil Science Society of America Journal, vol. 58, no. 6, pp. 1639-1645, 1994.

[51] A. J. Franzluebbers, R. L. Haney, C. W. Honeycutt, M. A. Arshad, H. H. Schomberg, and F. M. Hons, "Climatic 
influences on active fractions of soil organic matter," Soil Biology \& Biochemistry, vol. 33, no. 7-8, pp. 1103-1111, 2001.

[52] D. H. Buckley, V. Huangyutitham, T. A. Nelson, A. Rumberger, and J. E. Thies, "Diversity of Planctomycetes in soil in relation to soil history and environmental heterogeneity," Applied and Environmental Microbiology, vol. 72, no. 7, pp. 4522-4531, 2006.

[53] J. G. Kuenen, "Anammox bacteria: from discovery to application," Nature Reviews Microbiology, vol. 6, no. 4, pp. 320-326, 2008.

[54] S. Humbert, S. Tarnawski, N. Fromin, M. P. Mallet, M. Aragno, and J. Zopfi, "Molecular detection of anammox bacteria in terrestrial ecosystems: distribution and diversity," The ISME Journal, vol. 4, no. 3, pp. 450-454, 2010. 

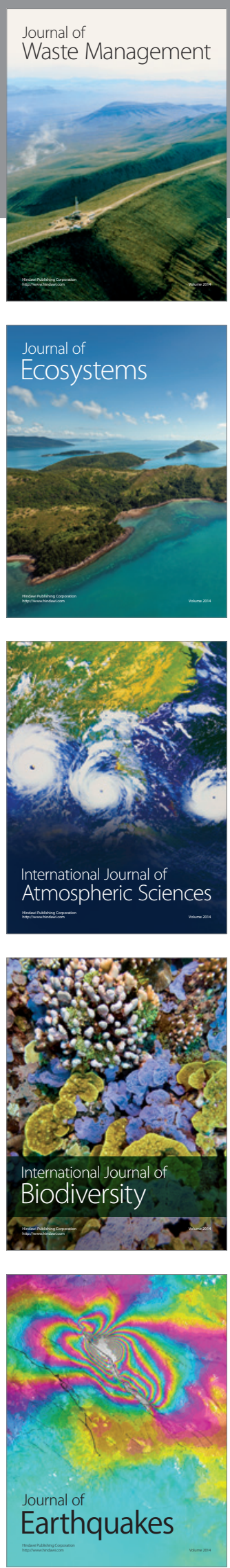
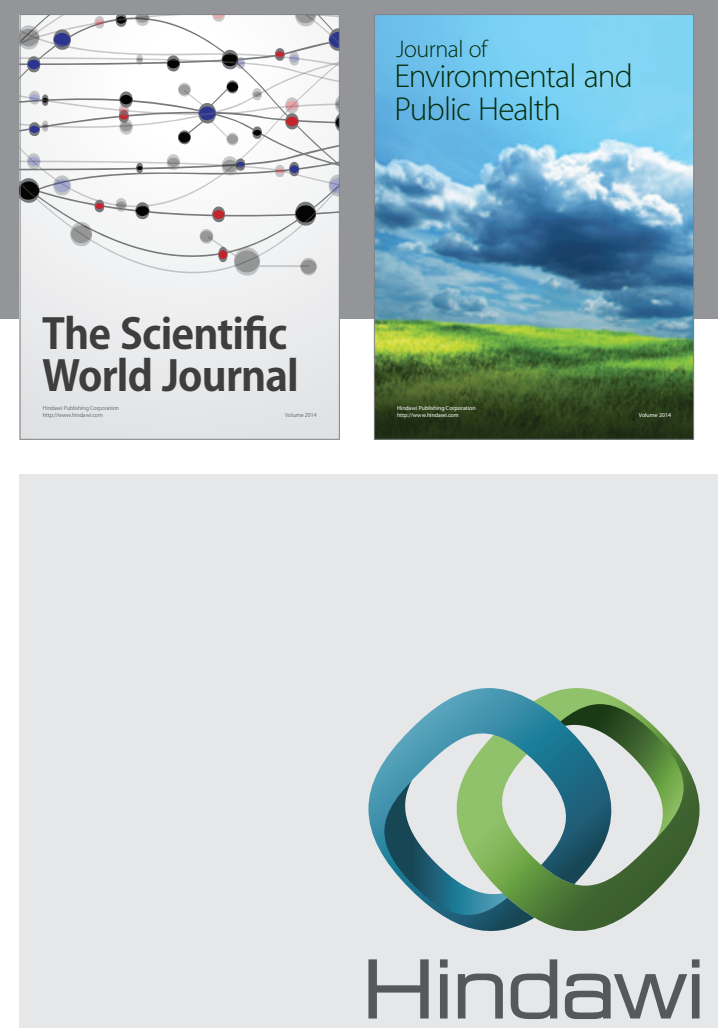

Submit your manuscripts at

http://www.hindawi.com
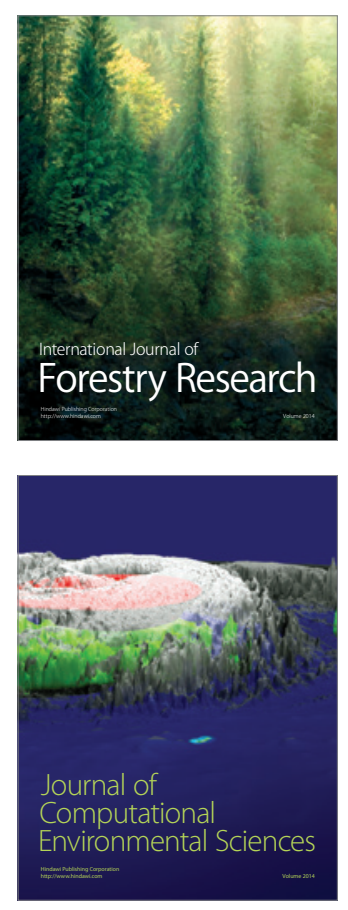
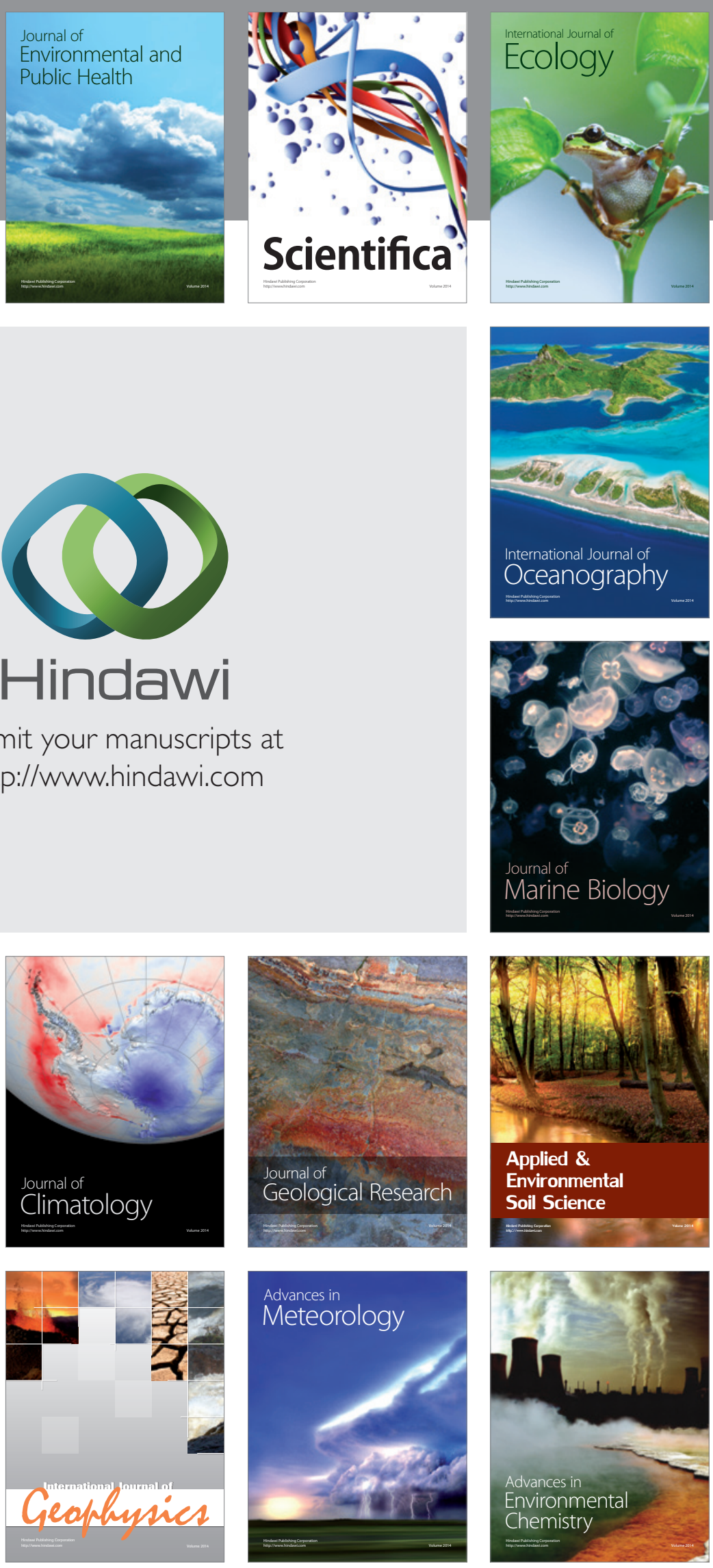